\title{
Disparitas Tindak Pidana Korupsi \\ (Pada Putusan Nomor 14/PID.SUS/ TPK/2016/PN.KDI dan Nomor 20/PID.SUS/TPK/2016/PN.KDI)
}

\author{
Disparitas Tindak Pidana Korupsi (on Decision No. 14/PID.SUS/ \\ TPK/2016/PN.KDI and No. 20/PID.SUS/TPK/2016/PN.KDI)
}

\author{
Riskanawati \\ Sekretariat Kota Kendari, Kecamatan Kendari Barat, Kelurahan Kemaraya \\ E-mail: riskainta5@yahoo.co.id \\ Oheo Kaimuddin Haris \\ Pascasarjana Universitas Halu Oleo \\ E-mail: oheo.haris@uho.ac.id \\ Handrawan \\ Pascasarjana Universitas Halu Oleo \\ E-mail: handrawansaranani84@gmail.com
}

\begin{abstract}
Criminal disparity becomes a separate problem in law enforcement in Indonesia, the absence of a criminal sanction guideline in imposing criminal sanctions is one of the causes of disparity. The seemingly limitless authority of judges is a cause of disparity, in addition, because the distance between minimum and maximum criminal sanctions is too large, in the absence of a guiding sentence for judges in criminal prosecution there will still be criminal disparities, therefore this study focuses on the principle of equality Proportionality between corruption actors whose object of the same case should be treated equally so that criminal disparities are expected not to cause injustice for the defendants, and justice seekers.
\end{abstract}

Keyword: Disparity; judge; Proportionality

Abstrak: Disparitas pidana menjadi problematika tersendiri dalam penegakkan hukum di Indonesia, tidak adanya Pedoman pemidanaan bagi hakim dalam menjatuhkan pidana menjadi salah satu penyebab disparitas. Kewenangan hakim yang seolah-olah tanpa batas menjadi penyebab disparitas, selain itu karena jarak antara Sanksi Pidana minimal dan maksimal itu terlampau besar, dengan tidak adanya Pedoman pemidanaan bagi hakim dalam penjatuhan pidana akan tetap terjadi Disparitas Pidana, oleh karenanya penelitian ini difokuskan pada asas kesamaan Proporsionalitas antara para Pelaku tindak Pidana Korupsi yang obyek perkaranya sama seharusnya diperlakukan sama sehingga Disparitas pidana diharapkan tidaklah menimbulkan ketidakadilan bagi Para terdakwa, dan para pencari keadilan.

Kata kunci: Disparitas; Hakim; Proporsionalitas. 


\section{PENDAHULUAN}

Disparitas pidana membawa problematika tersendiri dalam penegakkan hukum di Indonesia. Di satu sisi pemidanaan yang berbeda atau Disparitas Pidana merupakan bentuk dari diskresi hakim dalam menjatuhkan putusan, tetapi di sisi lain pemidanaan yang berbeda atau disparitas pidana ini pun membawa ketidakpuasan bagi Terpidana bahkan masyarakat pada umumnya.

Masalah kebebasan hakim dalam memutuskan perkara pidana yang ditanganinya menjadi faktor yang juga menimbulkan terjadinya disparitas pemidanaan. di Indonesia asas kebebasan hakim (judicial discretionary power) dijamin sepenuhnya dalam Pasal 1 Undang-undang No.4 tahun 2004 tentang Kekuasaan Kehakiman dimana dirumuskan bahwa kekuasaan kehakiman adalah kekuasaan negara yang merdeka untuk menyelenggarakan peradilan guna menegakkan hukum dan keadilan berdasarkan Pancasila, demi terselenggaranya Negara Hukum Republik Indonesia. Hakim sebagai penyelenggara kekuasaan kehakiman memperoleh kewenangan untuk memeriksa dan memutus perkara pidana yang ditanganinya secara bebas dari intervensi pihak mana pun. ${ }^{1}$

Namun demikian dalam hal menjatuhkan sanksi pidana, kebebasan hakim bukanlah tanpa batas. Asas Nulla Poena Sine Lege, dimana hakim hanya dapat memutuskan sanksi pidana berdasarkan jenis dan berat sanksi sesuai dengan takaran yang ditentukan oleh undang-undang. ${ }^{2}$

Dapat dipahami bahwa salah satu pembenaran disparitas pidana telah membawa hukum pidana kita kepada keadaan yang tidak lagi sesuai dengan tujuan penegak hukum. Hukum yang semula dimaksudkan untuk menjadi penjaga keadilan, kemanfaatan sosial, dan kepastian hukum tidak lagi dipenuhi secara utuh, dikarenakan unsur keadilan tidak lagi dirasakan oleh masyarakat dalam setiap putusan pengadilan hakim untuk menegakkan keadilan.

Hal tersebut pula di Pengadilan Negeri Kendari terdapat dua vonis pemidanaan yang dijatuhkan oleh hakim sebagaimana Perkara Nomor: 14/Pid.Sus/TPK/2016/PN.Kdi dengan terdakwa Drs. H. Priyono bin Atmomiharjo dan Putusan Nomor: 20/Pid.Sus/TPK/2016/PN.Kdi dengan terdakwa Sarno bin Sarman, yang Melakukan

1 Eva Achjani, Proporsionalitas Penjatuhan pidana, Jurnal Hukum dan Pembangunan Tahun ke-41 No. 2 April-Juni 2011

2 Ibid. 
Pungutan Dalam Kegiatan Sertipikasi Proyek Operasi Nasional Agraria (Prona) Kantor Pertanahan Kabupaten Wakatobi Tahun Anggaran 2012.

Disparitas Penjatuhan Putusan pidana yang terlampau jauh tersebut akan menimbulkan kesenjangan hukum, karena akan menimbulkan ketidakadilan. Adanya disparitas atas penjatuhan pidana yang dijatuhkan tentu saja membawa problem dalam penegakan hukum karena Para terdakwa diputus dengan hukuman yang berbeda-beda, sedangkan Para Terdakwa didakwa atas Perkara yang sama yaitu terkait Tindak Pidana Sertifikasi Prona di Kab. Wakatobi.

Berdasarkan Hal tersebut di atas Penulis melakukan penelitian terkait adanya disparitas pidana dalam tindak pidana korupsi. Maka yang menjadi permasalahan adalah apa Ratio Decidendi Disparitas Putusan dalam perkara Tindak Pidana korupsi dan Bagaimana Karakteristik Hukum disparitas Pidana pada Perkara Nomor: 14/Pid.Sus/TPK/2016/PN.Kdi dengan terdakwa Drs. H. Priyono Bin Atmomiharjo dan Putusan Nomor: 20/Pid.Sus/TPK/2016/PN.Kdi dengan terdakwa Sarno?

\section{METODE PENELITIAN}

Penelitian ini adalah Penelitian Hukum Penelitian (legal research, karakteristik penelitian hukum yakni mencari kebenaran koherensi yang mana suatu kebenaran di dasarkan pada kesesuaian antara yang ditelaah dengan aturan yang ditetapkan. Peter Mahmud Marzuki Mengatakan Penelitian hukum adalah suatu Proses untuk menentukan antara hukum, Prinsip-prinsip Hukum, maupun Doktrin-doktrin hukum guna menjawab isu hukum yang dihadapi. ${ }^{3}$

\section{ANALISIS DAN PEMBAHASAN}

\section{Analisa Ratio Decidendi Disparitas Putusan Tindak Pidana Korupsi Nomor:} 14/Pid.Sus/TPK/2016/Pn.Kdi dan Putusan Nomor:20/Pid. Sus/TPK/2016/Pn.Kdi Menurut Barda Nawawi Arief4, disparitas pidana adalah penerapan pidana yang tidak sama terhadap tindak pidana yang sama atau terhadap tindak pidana yang sifat bahayanya dapat diperbandingkan tanpa dasar pembenaran yang jelas. Disparitas pidana yang masih sering terjadi dapat berakibat fatal, akibat dari disparitas pidana dapat berdampak bagi 
terpidana dan masyarakat secara luas. Dampak disparitas pidana bagi terpidana yaitu, apabila terpidana setelah dijatuhi hukuman membandingkan pidana yang diterimanya.

Menurut Harkristuti Harkrisnowo disparitas pidana dapat terjadi dalam beberapa kategori yaitu5:

1. Disparitas antara tindak pidana yang sama

2. Disparitas antara tindak pidana yang mempunyai tingkat keseriusan yang sama

3. Disparitas pidana yang dijatuhkan oleh satu majelis hakim

4. Disparitas antara pidana yang dijatuhkan oleh majelis hakim yang berbeda untuk tindak pidana yang sama

Pada pertimbangan hukum terdapat 2 (dua) hal yang menjadi bagiannya, yaitu Ratio decidendi dan obiter Dictum. Ratio decidendi sebagai bagian pertimbangan tidak dapat dipisahkan dari amar putusan dan mempunyai kekuatan mengikat secara hukum yang dapat dirumuskan sebagai kaidah hukum. Selain itu terdapat bagian pertimbangan yang tidak mempunyai kaitan langsung dengan masalah hukum yang dihadapi dan karenanya juga tidak berkaitan dengan amar putusan, bagian ini disebut dengan obiter dictum. Bagian pertimbangan ini sering dilakukan karena digunakan sebagai ilustrasi atau analogi dalam menyusun argumen pertimbangan hukum, yang dalam hal ini obiter dictum sifatnya tidak mempunyai kekuatan hukum yang mengikat. ${ }^{6}$

Putusan hakim sebagai proses akhir dalam penegakan hukum, Putusan pengadilan merupakan Output suatu proses peradilan di Sidang Pengadilan yang meliputi Proses Pemeriksaan saksi-saksi, Pemeriksaan terdakwa, Pemeriksaan Barang bukti.

Secara formal terdapat 2 (dua) hal yang harus dipertimbangkan oleh hakim sebelum menjatuhkan putusannya, ketentuan mengenai dua hal tersebut sebagaimana diatur di dalam kitab Undang-undang Hukum Acara Pidana (KUHAP), dimana struktur pengambilan keputusan adalah: pertama pertimbangan tentang fakta-fakta (apakah terdakwa benar-benar melakukan perbuatan yang dituduhkan kepadanya); kedua pertimbangan tentang hukumnya (apakah perbuatan terdakwa merupakan tindak pidana dan terdakwa bersalah), sehingga bisa dijatuhi putusan pidana. ${ }^{7}$

5 Harkristuti Harkrisnowo, Rekonstruksi Konsep Pemidanaan: Suatu Gugatan Terhadap Proses Legislasi dan Pemidanaan di Indonesia", dalam majalah KHN Newsletter, Edisi April 2003, Jakarta: KHN. hlm. 28.

6 Mahkamah Konstitusi, Hukum Acara Mahkamah Konstitusi, Cet. I, Jakarta: Sekretaris Jenderal dan kepaniteraan MKRI, 2010, hlm. 190.

7 Tendik Wijaksono, Penjatuhan Pidana Oleh Hakim di bawah Batas Minimum Khusus Dari Ketentuan Undang-Undang, Dalam Perkara Tindak Pidana Narkotika, Fakultas hukum, program Pasca Sarjana Universitas Indonesia, 2011, hlm. 102 
Terdakwa H. Priyono dan Sarno dihadapkan di pengadilan Tindak pidana Korupsi Pada pengadilan Negeri Kendari dengan kerugian negara kerugian keuangan negara sebesar Rp.644.997.000,- (enam ratus empat puluh empat juta sembilan ratus sembilan puluh tujuh ribu rupiah) dalam kegiatan Sertipikasi Proyek Nasional (PRONA) Pada Kab. Wakatobi Tahun anggaran 2012, berdasarkan Putusan Pengadilan Para Terdakwa dinyatakan terbukti secara sah dan meyakinkan bersalah melakukan tindak pidana "Korupsi Secara Bersama-sama" sebagaimana dalam Dakwaan Kesatu Subsider dan Dakwaan Kedua Penuntut Umum yaitu Pasal 3 UU No. 31 Tahun 1999 sebagaimana telah diubah dan ditambah dalam UU No. 20 Tahun 2001, tentang Tindak Pidana Korupsi jo. Pasal 55 ayat (1) Ke-1 KUHP, dan; Pasal 12 huruf e Undang-Undang No. 31 tahun 1999 tentang Pemberantasan Tindak Pidana Korupsi yang telah diubah dengan Undang-Undang No. 20 tahun 2001 tentang Perubahan atas Undang-Undang No. 31 tahun 1999 tentang pemberantasan tindak Pidana Korupsi Jo. Pasal 55 atar (1) Ke-1

Terhadap Putusan Hakim yang dijatuhkan kepada Terdakwa H. Priyono dan Sarno terdapat perbedaan (disparitas) baik terhadap Pidana denda Maupun Pidana tambahan berupa uang pengganti.

Penjatuhan Pidana yang berbeda harus didasarkan pada alasan-alasan yang jelas dan dapat dibenarkan. Pandangan ini sejalan dengan asas kebebasan hakim dalam menjatuhkan putusan terhadap perkara yang diajukan padanya. dimana hakim dalam usahanya untuk tetap menjaga kewibawaan hukum, harus dapat mempertanggungjawabkan putusan yang dihasilkannya dengan memberikan alasan yang benar dan wajar tentang perkara yang diperiksanya.

Menghadapi problematika disparitas pidana diperlukan penghayatan hakim terhadap asas proporsionalitas dalam menjatuhkan pidana kepada Para terdakwa yang sifat dan obyek perkara yang sama hal ini pula demi, kepentingan si pelaku tindak pidana dan kepentingan korban tindak pidana, serta kepentingan negara karena terkait dengan keuangan negara. Karena untuk menghilangkan disparitas pidana sama sekali adalah tidak mungkin, yang perlu diusahakan adalah pemidanaan yang tepat dan serasi.

Ide tentang proporsionalitas pidana lebih banyak terkait dengan tujuan Penjatuhan pidana oleh hakim yang termuat dalam putusannya, seperti terdakwa harus dipidana setimpal dengan perbuatannya, Telah sesuai dengan akibat yang ditimbulkan oleh 
perbuatan, atau terdakwa harus dipidana yang sesuai dan setimpal dengan kesalahannya. Prinsip kesetimpalan Merupakan istilah lain dari Proporsionalitas. ${ }^{8}$

Pemidanaan tidak dimaksudkan untuk mencapai keserasian putusan mutlak, karena hal tersebut akan bertentangan dengan prinsip kebebasan hakim, aturan batas maksimal dan minimal pemidanaan dan bertentangan pula dengan rasa keadilan dan keyakinan hakim. Keserasian tersebut bukanlah untuk memberikan pidana yang sama, tetapi menjadikan falsafah pemidanaan yang tepat dan serasi berdasarkan asas Proporsinalitas pemidanaan, dan berdasarkan Prinsip Proporsionalitas pidana, setidaknya diancam dengan pidana yang sama atau dapat diperbandingkan beratnya berdasarkan kerugian yang ditimbulkan dan kesalahan.

\section{Karakteristik Hukum disparitas Pidana}

Faktor yang dapat menyebabkan timbulnya disparitas pidana adalah tidak adanya pedoman pemidanaan bagi hakim dalam menjatuhkan pidana. Sudarto mengatakan bahwa pedoman pemberian pidana akan memudahkan hakim dalam menetapkan pemidanaannya, setelah terbukti bahwa terdakwa telah melakukan perbuatan yang didakwakan kepadanya. ${ }^{9}$

Ciri khas keadilan dan hubungan spesialnya dengan hukum mulai muncul jika kita mengamati bahwa sebagian besar kritik yang dibuat dalam tinjauan adil dan tidak adil hampir sama bisa diungkapkan dengan kata "fair" (berimbang) dan "unfair" (tidak berimbang). Keberimbangan jelas tidak berdampingan dengan moralitas secara umum; penunjukan pada istilah ini terutama relevan dalam dua situasi kehidupan sosial. Yang satu adalah ketika kita membahas bukan perilaku seorang individu melainkan cara diperlakukannya kelas-kelas individu, ketika beban atau manfaat tertentu hendak didistribusikan di antara mereka. Dengan demikian, di sini apa yang disebut sebagai berimbang atau tidak berimbang biasanya merupakan "jatah atau bagian”. Situasi kedua adalah Ketika kerugian tertentu telah diperbuat dan muncul klaim ganti tugi (kompensasi) atau penawarnya. ${ }^{10}$

Hal tersebut senada dengan pendapat Leo Polak yang mengemukakan bahwa salah satu syarat dalam pemberian pidana adalah beratnya pidana harus seimbang dengan

\footnotetext{
8 Mahrus Ali, Proporsionalitas dalam Kebijakan Formulasi Sanksi Pidana, Jurnal Hukum Ius Quia Iustum No. 1 Vol 25. 2018, hlm. 138.

9 Sudarto, Hukum dan Hukum Pidana, Bandung: Alumni, Bandung, 1986, hlm. 9.

10 H.L.A Hart, Konsep Hukum, diterjemahkan oleh M. Khozim, Bandung: Nusa Media, 2009, hlm. 245-246.
} 
beratnya delik. Beratnya pidana tidak boleh melebihi beratnya delik, hal ini diperuntukkan supaya penjahat tidak dipidana secara tidak adil. Berkaitan dengan tujuan diadakannya batas maksimum dan minimum adalah untuk memberikan kemungkinan pada hakim dalam memperhitungkan bagaimana latar belakang dari kejadian, yaitu dengan berat ringannya delik dan cara delik itu dilakukan, pribadi si pelaku delik, umur, dan keadaankeadaan serta suasana waktu delik itu dilakukan, di samping tingkat intelektual atau kecerdasannya. ${ }^{11}$

Sebab sistem peradilan pidana sebagai sistem penegakan hukum dengan sendirinya harus mencerminkan adanya perlindungan terhadap hak-hak tersangka/terdakwa. Sedangkan hak-hak tersangka atau terdakwa yang terdapat dalam sistem peradilan pidana merupakan prasyarat terselenggaranya proses hukum yang adil. ${ }^{12}$

Keadilan selain merupakan tujuan hukum juga merupakan roh dalam setiap putusan sehingga keadilan terletak dalam irah-irah setiap putusan "Demi Keadilan berdasarkan Tuhan Yang Maha Esa"13

Oleh karenanya adanya putusan disparitas pidana dalam perkara Tindak Pidana Korupsi, dimana disparitas pidana dapat terjadi pada pemidanaan yang tidak sama terhadap mereka yang melakukan bersama suatu tindak pidana seperti halnya dalam Perkara Terdakwa H. Priyono dan Sarno yang memiliki Karakteristik hukum yang sama akan tetapi kemudian Putusan yang dijatuhkan berbeda, Di sinilah disparitas pemidanaan mempunyai dampak yang dalam, karena di dalamnya terkandung perimbangan konstitusional antara kebebasan individu dan hak negara untuk memidana.

Dengan adanya putusan perkara dalam tindak Pidana Korupsi yang menerapkan disparitas pidana seperti perkara Terdakwa H. Priyono dan Sarno dengan pertimbangan jumlah kerugian keuangan negara yang berbeda (terjadi perubahan jumlah kerugian keuangan negara) terhadap perkara yang diputus dalam perkara yang sama maka putusan tersebut dimungkinkan untuk dikoreksi pada tingkat peradilan yang lebih tinggi, dengan mengadili sendiri.

11 Djoko Prakoso dan Nurwachid, Studi tentang Pendapat-Pendapat Mengenai Efektivitas Pidana Mati di Indonesia, Jakarta: Ghalia Indonesia, 1983, hlm. 20.

12 Heri Tahir, Proses hukum yang Adil dalam Sistem Peradilan Pidana di Indonesia, Yogyakarta: Laksbang, 2010, hlm. 9.

13 Bismar Siregar. Mendekatkan Hukum dengan Keadilan Tuhan, Seminar Hut Kosgoro ke-36 Garut, 25 Desember 1993. 


\section{KESIMPULAN}

Berdasarkan Hasil Penelitian ini dan pembahasan sebagaimana diuraikan di atas, maka dirumuskan kesimpulan sebagai berikut:

1. Ratio Decidendi dalam Penjatuhan Putusan Pertimbangan hakim dibagi menjadi dua yaitu pertimbangan yang bersifat yuridis yang didasarkan pada fakta persidangan dengan bersandar pada alat bukti serta peraturan hukum yang terkait dan pertimbangan non-yuridis yaitu alasan pemberat dan yang meringankan. sehingga untuk menentukan berat ringannya pidana yang dijatuhkan sepenuhnya diserahkan kepada hakim bahwa dalam hal pemeriksaan perkara Terdakwa H. Priyono dipisah menjadi 2 Berkas (splitsing) dimana perkara tersebut memiliki ciri dan karakteristik yang sama yaitu Tindak pidana Korupsi Sertifikasi Prona pada Kab. Wakatobi, dakwaan, tuntutan, Kemudian pembuktian Pasal yang dikenakan sama sehingga penjatuhan pidana tidaklah harus berbeda akan tetapi diperlakukan sama sebagaimana asas Proporsionalitas, oleh karenanya Penulis berkesimpulan telah terjadi disparitas dalam penjatuhan pidana yang dilandasi oleh asas Proporsional. terjadinya disparitas pidana, tersebut juga dipengaruhi oleh ideologi Hakim atau pemikiran dan falsafah pemidanaan yang berbeda antara pembalasan dan pembinaan.

2. Karakteristik hukum Pada perkara Nomor 14 /Pid.Sus/TPK/2016/Pn.Kdi dan Putusan Nomor 20/Pid.Sus/TPK/2016/Pn.Kdi. adalah peristiwa hukum yang sama dengan keadaan yang sama haruslah diperlakukan sama berdasarkan asas persamaan Proporsional, sehingga jika diperlakukan berdasarkan asas persamaan Proporsional maka seharusnya putusan pemidanaan tersebut juga sama.

Berdasarkan kesimpulan sebagaimana telah dirumuskan di atas, maka dapat ditarik Rekomendasi sebagai berikut:

1. Perlu ada suatu pedoman bagi hakim yang dituangkan dalam SEMA dengan mengklasifikasikan jumlah kerugian negara dan menetukkan perkiraan lama penjatuhan pidana kurungan dan menentukan jenis pemidanaan yang tepat dijatuhkan kepada para terdakwa, sehingga hakim dapat menjatuhkan pidana yang tepat dan memenuhi rasa keadilan bagi terdakwa, untuk menghindari Disparitas Pidana. 
2. Selain adanya pedoman, kirannya juga dalam memeriksa dan memutus perkara tindak pidana korupsi penyertaan/turut serta, yang ciri dan karakteristiknya sama, mulai dari dakwaan, tuntutan, pemeriksaan bukti dan saksi, kiranya diperiksa dan diputus oleh majelis hakim yang sama.

\section{Daftar Pustaka}

\section{Buku}

Hart, H.L.A, Konsep Hukum, diterjemahkan oleh M. Khozim, Bandung: Nusa Media, 2009. Mahkamah Konstitusi, Hukum Acara Mahkamah Konstitusi, Cet. I, Jakarta: Sekretaris Jenderal dan Kepaniteraan MKRI, 2010.

Marzuki, Peter Mahmud, Penelitian Hukum, Jakarta: Kencana Prenada Media Group, 2005. Muladi, Barda Nawawi Arief, Teori-Teori dan Kebijakan Pidana, Bandung: Alumni, 1992. Prakoso, Djoko dan Nurwachid, Studi tentang Pendapat-Pendapat Mengenai Efektivitas Pidana Mati di Indonesia, Jakarta: Ghalia Indonesia, 1983.

Sudarto, Hukum dan Hukum Pidana, Bandung: Alumni, 1986.

Tahir, Heri, Proses Hukum yang Adil dalam Sistem Peradilan Pidana di Indonesia, Yogyakarta: Laksbang, 2010.

\section{Makalah dan Jurnal}

Achjani, Eva, Proporsionalitas Penjatuhan pidana, jurnal Hukum dan Pembangunan tahun ke-41 No.2 April-Juni 2011

Ali, Mahrus, Proporsionalitas dalam Kebijakan Formulasi Sanksi Pidana, jurnal Hukum ius Quia Iustum No.1 Vol 252018.

Harkrisnowo, Harkristuti, Rekonstruksi Konsep Pemidanaan: Suatu Gugatan Terhadap Proses Legislasi dan Pemidanaan di Indonesia", dalam majalah KHN Newsletter, Edisi April 2003, Jakarta: KHN.

Siregar, Bismar. Mendekatkan Hukum dengan Keadilan Tuhan, Seminar Hut Kosgoro ke-36 Garut, 25 Desember 1993.

Wijaksono, Tendik, Penjatuhan Pidana Oleh Hakim di bawah Batas Minimum Khusus dari Ketentuan Undang-Undang, dalam Perkara Tindak Pidana Narkotika, Fakultas Hukum, Program Pasca Sarjana Universitas Indonesia, 2011. 